\title{
THE INTERACTING AREAS OF REGULATORY AU. THORITY IN PUBLIC UTILITIES
}

\section{Gustavus H. Robinson}

The last few years show a constant enlargement of the category of the business enterprises over which the Federal government exercises its regulatory authority. Since regulation connotes that the regulator is bigger than the regulated, and the regulated insists on vast size, business organization on national scale causes the states, it seems necessarily, to lose power to an authority which still continues larger than any of the enterprises it deals with. It is the growth of Federal government activities, therefore, which marks the period generally. As to the utility, the United States government entered the field of direct control through the use of the Interstate Commerce Commission in I887. Originally confined to railroads, the jurisdiction of that body has been expanded to cover other interstate communication; to pipe lines, express companies, sleeping car companies, telegraph, telephone and cable companies. It might appear that it is due to be the controller, for the Federal authority, of all forms of communication or transportation. Yet radio matters, and labor matters, even in the industries already in the Commerce Commission's hands, have gone to special commissions. The motor bus in interstate commerce must have a Federal regulation, but whether it will be by the Commerce Commission is not decided; the scheme for superpower transmission must expect Federal regulation. ${ }^{1}$ Logically it may be better to have it all in the hands of one body. Certainly it seems inadvisable to give railroads and their rates to the Commerce Commission and not give railroad wages to the same authority. But perhaps the answer lies in a sense that the Commerce Commission is already overburdened, and in a vague dread of surrendering to any one

'See (Ig27) 40 Harv. L. REv. 906, note to Attleboro, etc., Co. v. P. U. Comm., 273 U. S. 83 (I927). 
authority such vast powers. It appears likely, on the whole, that the Interstate Commerce Commission is ceasing to be the residuary legatee as to the new enterprises over which the Federal authority extends.

But although the Congressional trend to give the Commission jurisdiction over more enterprises may be checked, the extent of the Commission's authority over the types of utility to which it has been applied has constantly been deepened. Since the Transportation Act of Ig2o the Interstate Commerce Commission holds the Federal mandate to view the railroads as a unit serving as a unit the whole country and to treat them accordingly. This national view as interpreted by the Supreme Court in the $W$ isconsin Passenger Fares case ${ }^{2}$ frowns upon the possibility that financially weak intrastate portions of the railroad business may draw sustenance from the interstate parts. The Court there said:

"Congress in its control of the interstate commerce system is seeking in the Transportation Act to make the system adequate to the needs of the country by securing for it a reasonably compensatory return for all the work it does. The states are seeking to use that same system for intra-

${ }^{2}$ After briefly reviewing it in Railroad Commission of Wisconsin v. Chicago, Burlington \& Quincy R. R. Co. (Wisconsin Passenger Fares Cases) 257 U. S. 563 (1922), Chief Justice Taft says "It is manifest from this very condensed recital that the act made a new departure. Theretofore the control which Congress, through the Interstate Commerce Commission, exercised, was primarily for the purpose of preventing injustice by unreasonable or discriminatory rates against persons and localities, and the only provisions of the law that inured to the benefit of the carriers were the requirements that the rates should be reasonable in the sense of furnishing an adequate compensation for the particular service rendered, and the abolition of rebates." See also Akron, Canton, etc., Ry. Co. v. United States (New England Divisions Case) 26I U. S. I84 (I923). Mr. Justice Brandeis in Texas \& Pacific Ry. Co. v. Gulf, C. \& S. F. Ry. Co., 270 U. S. 266 (I926) says of the Transportation Act: "By that measure, Congress undertook to develop and maintain, for the people of the United States, an adequate railway system. It recognized that preservation of the earning capacity, and conservation of the financial resources, of individual carriers is a matter of national concern; that the building of unnecessary lines involves a waste of resources, and that the burden of this waste may fall upon the public; that competition between carriers may result in harm to the public, as well as in benefit; and that, when a railroad inflicts injury upon its rival, it may be the public which ultimately bears the loss. See also Railroad Commission v. Chicago, Burlington \& Quincy R. Co., 257 U. S. 563 (I922); The New England Divisions Case, 26r U. S. I84 (1923); The Chicago Junction Case, 264 U. S. 258 (I924) ; Railroad Commission v. Southern Pacific Co., 264 U. S. 33 I (I924). The Act sought, among other things, to avert such losses." 
state traffic. That entails large duties and expenditures on the interstate commerce system which may burden it unless compensation is received for the intrastate business reasonably proportionate to that for the interstate business. Congress, as dominant controller of interstate commerce, may, therefore, restrain undue limitation of the earning power of the interstate commerce system in doing state work. The affirmative power of Congress in developing interstate commerce agencies is clear. In such development, it can impose any reasonable condition on a state's use of interstate carriers for intrastate commerce it deems necessary or desirable. This is because of the supremacy of the national power in this field."

The discussion which follows aims to show what effect the new background thus set forth has had upon the State and Federal areas of regulatory authority.

The earlier doctrine which gives to the Interstate Commerce Commission an authority over intrastate rates when they operate to work discrimination against interstate commerce is now well known. ${ }^{3}$ It was startling enough in its day, but it involved

${ }^{3}$ Houston and E. \& W. Texas Ry. Co. v. U. S. (Shreveport Rate Cases) 234 U. S. 342 (I914). "Undoubtedly-in the absence of a finding by the Commission of unjust discrimination-intrastate rates were left to be fixed by the carrier and subject to the authority of the States or of the agencies created by the States. This was the question recently decided by this court in the Minnesota Rate Cases, 230 U. S. 352 (I9I3). There, the state of Minnesota had established reasonable rates for intrastate transportation throughout the State and it was contended that, by reason of the passage of the Act to Regulate Commerce, the state could no longer exercise the state-wide authority for this purpose which it had formerly enjoyed; and the court was asked to hold that an entire scheme of intrastate rates, otherwise validly established, was null and void because of its effect upon interstate rates. There had been no finding by the Interstate Commerce Commission of any unjust discrimination.

"Here, the Commission expressly found that unjust discrimination existed under substantially similar conditions of transportation and the inquiry is whether the Commission had power to correct it. We are of the opinion that the limitation of the proviso in section one does not apply to a case of this sort. This is plainly the case when the Commission finds that unjust discrimination against interstate trade arises from the relation of intrastate to interstate rates as maintained by a carrier subject to the act. Such a matter is one with which Congress alone is competent to deal, and, in view of the aim of the act and the comprehensive terms of the provisions against unjust discrimination, there is no ground for holding that the authority of Congress was unexercised and that the subject was thus left without governmental regulation. We are convinced that the authority of the Commission was adequate."

The case has a considerable literature of its own. See the effect of the Shreveport Rate Cases categorically stated in a confirming decision in Illinois Central R. R. v. P. U. Commission of Ill., 245 U. S. 493 (rgr8), at 506-7 and 
no such upsetting of what had been the formula, namely, that interstate matters were for the Commerce Commission and intrastate matters for the states, as did the Wisconsin Passenger Fares case ${ }^{4}$ in 1922 , for in the latter instance the whole intrastate rate structure was affected by the Federal Commission's order. That body

"had investigated the interstate rates of carriers in the United States, in a proceeding known as Ex parte 74, Increased Rates, ${ }^{5}$ for the purpose of complying with Section I $5 \mathrm{a}$ of the Interstate Commerce Act, as amended by Section 422 of the Transportation Act of $1920 .{ }^{6}$ That section requires that the Commission so adjust rates that the revenues of the carriers shall enable them as a whole or by groups to earn a fixed net income on their railway property. The Commission ordered an increase for the carriers in the group of which the Wisconsin carriers were a part. The Wisconsin Railroad Commission then granted increases in intrastate freight rates but denied any in intrastate passenger fares on the sole ground that a state statute prescribed a two-cent maximum.

"Since all of the carriers transported both intrastate and interstate passengers on the same train, with the same service and accommodations, the findings of the Commerce Commission were that there was undue . . . discrimination against persons traveling in interstate commerce and against interstate commerce as a whole; and ordered that the undue discrimination be removed by increases in all intrastate fares . . . corresponding with the increases . . . ordered in interstate business."

The joyful carriers filed bills in equity to enjoin the state commission from interfering with this bounty and the case came

notes to this case (IgI8) I6 MICH. L. Rev. 379; (I9I8) I8 CoL. L. REv. 270; (IgI8) 3 I HARV. L. REV. IO3I. Notes on Shreveport Case, (I92I) 69 U. OF PA. L. Rev. 262; (I9I4) I4 CoL. L. Rev. 583; (IgI4) 28 HARv. L. Rev. II3. See H. W. Biklé, Federal Control of Intrastate Railroad Rates (IgI4) 63 U. OF PA. L. REv. 69.

"R. R. Comm. of Wisc. v. Chicago, B. \& Q. R. R. Co., 257 U. S. 563 (1922). A "charter contract," between the state and the railroad, for a two cents per mile passenger fare furnishes no vehicle for the avoidance of the Commission's order: New York v. U. S., 257 U. S. 59 I (I922).

58 Interst. Com. Rep. 220 (1920).

${ }^{\circ} 4$ I Stat. 488 (I920). 
to the Supreme Court from a decision in their favor. In affirming it Chief Justice Taft, who wrote for a unanimous court, pointed out at once that

"The order in this case, however, is much wider than the orders made in the proceedings following the Shreveport and Illinois $C$. R. Co. cases. There, as here, the report of the Commission showed discrimination against persons and localities at border points, and the orders were extended to include all rates or fares from all points in the state to border points. But this order is not so restricted. It includes fares between all interior points, although neither may be near the border, and the fares between them may not work a discrimination against interstate travelers at all. Nothing in the precedents cited justifies an order affecting all rates of a general description. . . We cannot sustain the sweep of the order in this case on the showing of discriminations against persons or places alone.

"The report of the Commission shows that if the intrastate passenger fares in Wisconsin are to be limited . . . to two cents per mile, . . . the net income of the interstate carriers of the state will be cut six millions of dollars below what it would be under intrastate rates on the same level with interstate rates. . . .

"Under title 4 (of the Igro Act) amendments were made to the Interstate Commerce Act which included Section I3, pars. 3 and 4 , and Section I5a. The former for the first time authorizes the Commission to deal with intrastate rates where they are unduly discriminating against interstate commerce, - a power already indirectly exercised as to persons and localities, with approval of this court, in the Shreveport and other cases. The latter, the most novel and most important feature of the Act, requires the Commission so to prescribe rates as to enable the carriers as a whole, or in groups selected by the Commission, to earn an aggregate annual net railway operating income equal to a fair return on the aggregate value of the railway property used in transportation. . . ."

The new measure imposed an affirmative duty on the Interstate Commerce Commission to fix rates and to maintain an adequate service for the people of the United States. This is expressly declared in Section I5a to be one of the purposes of the bill. 
"Intrastate rates and the income from them must play a most important part in maintaining an adequate national railway system. Twenty per cent. of the gross freight receipts of the railroads of the country are from intrastate traffic, and fifty per cent. of the passenger receipts. . . . If the railways are to earn a fixed net percentage of income, the lower the intrastate rates, the higher the interstate rates may have to be. The effective operation of the $A c t$ will reasonably and justly require that intrastate traffic should pay a fair proportionate share of the cost of maintaining an adequate railway system.

"When we turn to par. 4, Section I3, [we] find the Commission for the first time vested with a direct power to remove 'any undue, unreasonable, or unjust discrimination against interstate or foreign commerce,' [and] it is impossible to escape the dovetail relation between that provision and the purpose of Section I5a. If that purpose is interfered with by a disparity of intrastate rates, the Commission is authorized to end the disparity by directly removing it, because it is plainly an 'undue, unreasonable, and unjust discrimination against interstate or foreign commerce,' within the ordinary meaning of those words." 7

Municipal pride urging a monumental union station was checked in The Railroad Commission of California v. Southern Pacific Railway, et al.,8 when the state commission's order for one at Los Angeles was upset because it involved an outlay of $\$ 25,000,000$ to $\$ 45,000,000$. Such extended capital expendi-

TThe decision was widely commented upon. See note to the case: (1922) 35 HARv. L. REv. 864; (Ig23) 36 HARv. L. REv. I4; (Ig22) 2 WIS. L. REv. 56; (I922) 20 MiCH. L. REv. 675; (I922) 6 MINN. L. REv. 675; (I922) 8 VA. L. REv. 6I5; McCallester, (I922) 3I Y YLE L. J. 870-9; James M. Beck, Federal Power over Intrastate Railroad Rates, (I922) $7 \mathrm{I}$ U. of PA. L. REv. II; T. R. Powell, The Supreme Court Decisions on the Commerce Clanse and State Police Powers, (I92I) 21 CoL. L. REv. 737; (1922) 22 CoL L. REv. 28; and The Supreme Court's Adjudication of Constitutional Isstes in I921, I922, (I922) 21 MICH. L. REV. I74, I77. In I924 after the decision of Dayton Goose Creek Ry. v. United States (The Recapture of Earnings Cases) 263 U. S. 456 (I924), a writer in (I924) 37. HARv. L. REv. 888 , heads his note, "The waning power of the states over railroads: curtailment of state regulatory activities by the Transportation Act" and concludes, "Although it is too early to observe the complete effect of the Act upon the States' police power, it is clear already that it has achieved a single, nationally-minded regulation of the larger phases of transportation. State regulation is now decidedly confined to matters of routine administration requiring a knowledge of conditions peculiarly local."

${ }^{8} 264$ U. S. 33I (Ig24). 
tures on state say-so were held to be outside the state jurisdiction. Said Chief Justice Taft:

"It is obvious from the foregoing (analysis of the $I 920$ $A c t)$ that Congress intended to place under the superintending and fostering direction of the Interstate Commerce Commission all increased facilities in the matter of distribution of cars and equipment and in joint terminals in the exchange of interstate traffic and passengers between railways so as to make it prompt and continuous. It not only provides for the temporary expropriation of terminals and main track of one railway to the common use of one or more other railways in an emergency, but it also contemplates the compulsory sharing of one company's terminals with one or more companies as a permanent arrangement. This is a drastic limitation of a carrier's control and use of its own property in order to secure convenience and dispatch for the whole shipping and traveling public in interstate commerce. It gives to the Interstate Commerce Commission the power and duty, where the public interest requires, to make out of what is the passenger and freight station of one interstate carrier, a union station or depot.

"We think it clear that in such an extension of main lines with their terminals the Interstate Commerce Commission is required by the $A c t$ to make a finding that the expense involved will not impair the ability of the carriers concerned to perform their duty to the public. (As required by Section 402 , par. 2I.)

"Until the Interstate Commerce Commission shall have acted under paragraphs I8 to 21 of Section 402 of the Transportation $A c t,{ }^{9}$ the respondent railways can not be re-

\footnotetext{
- The requirement was added by the Transportation Act of I920, \$§ I8-20. See Texas v. E. Texas R. Co., 258 U. S. 204 (1922), Mr. Justice VanDevanter: "By sec. 402 of the Transportation Act of 1920, c. 9I, 4I Stat. 456, 477, several new paragraphs were added to sec. I of the Act to Regulate Commerce as theretofore amended. By them Congress has undertaken to regulate the construction and acquisition of new or additional lines of railroad and the extension and abandonment of old lines, and to invest the Interstate Commerce Commission with important administrative powers in that connection.

"They declare that 'no carrier by railroad subject to this act shall abandon all or any portion of a line of railroad, or the operation thereof, unless and until there shall first have been obtained from the Commission a certificate that the present or future public convenience and necessity permit of such abandonment' (par. 18); that when application for such a certificate is received the Commission shall cause notice thereof to be given to the Governor of the State wherein the line lies and publish in newspapers of general circulation in each county along the line, and shall accord a hearing to the State and all parties in
} 
quired to provide a new interstate union station and to extend their main tracks thereto as ordered by the State Railroad Commission."

In Colorado v. United States, ${ }^{10}$ the decision upholding an order that an anæmic intrastate branch of an interstate road should no longer draw sustinence from the general system was another phase of the unity idea applied to finances. The court said, by Brandeis, $J$.:

"Control is exerted over intrastate commerce only because such control is a necessary incident of freeing interstate commerce from the unreasonable burdens, obstruction or unjust discrimination which are found to result from operating a branch at a large loss. . . . The exertion of the federal power to prevent prejudice to interstate commerce so arising . . . is similar to that exerted when a state establishes intrastate rates so low that intrastate traffic does not bear its fair share of the cost of the service, . . . or when state authorities seek to compel the erection of a union station so expensive as unduly to deplete the financial resources of the carriers, . . . or when one road seeks to construct an intrastate branch which would do so. . . ."

interest (par. Ig); that the Commission may grant or refuse the certificate in whole or in part and impose such terms and conditions as in its judgment the public convenience and necessity require; and that when the certificate is issued, and not before, the carrier may, 'without securing approval other than such certificate, comply with the terms and conditions imposed and proceed with the abandonment covered by the certificate (par. 20)."

The distinction between "extensions" and "spurs" is being worked out by the Supreme Court: Texas \& P. Ry. Co. v. Gulf C. \& S. F. Ry., 270 U. S. 266 (I926), "where the proposed trackage extends into new territory not heretofore served by the carrier, and particularly when it extends into territory already served by another carrier, its purpose and effect are under the new policy of Congress of national concern," said Brandeis, J. See note (1926) 39 HARV. I. REv. 753. See also Alabama \& V. Ry. Co. v. Jackson \& E. Ry. Co., 27I U. S. 244 (I926) discussed infra. For a discussion of the Commission's reading of the statute to require that its certificate issue in cases where a new company seeks to operate old lines, see R. T. Swaine, Reorganization of Corporations (I928) 28 COL. L. REv. 29, 37.

The new act also gives the Interstate Commerce Commission the supervision of new issues of capital securities. The probability that they would be required to finance the Los Angeles project was a distinct make weight against the state. See Waning Power of the States over Railroads (I924) 37 HARv. L. REv. 888; and on the 1920 Act to 1922 a note in (1922) 2 WIS. L. REv. 56 ; and E. C. Buckland, Three Years of the Transportation Act, (I923) 32 YALE L. J. 658 .

$$
{ }^{10} 27 \text { U. S. } 153 \text { (1926). }
$$


Against such a background as that just indicated, a recent decision of the Circuit Court of Appeals for the Fifth Circuit offers elements of surprise. In Texas and New Orleans $R y . v$. Northside Belt Ry., ${ }^{11}$ the Texas and New Orleans sought to block the construction of the projected Northside road which contemplated doing a half and half interstate and intrastate business and which had made no application to the Interstate Commerce Commission for a certificate of convenience. The District Court held that until a new road is actually undertaking to do interstate business the Commerce Commission is without jurisdiction. It dismissed the bill without prejudice to an application later if the future activities "shall bring it over properly within the purview of the act." This decree was affirmed by the Circuit Court of Appeals, but it seems a matter of no astonishment ${ }^{12}$ that the Supreme Court has granted a writ of certiorari ${ }_{r}{ }^{13}$

Both the Commerce Commission's own view and that of an interested state is against the holding in the Fifth Circuit, as was evidenced when the Illinois Central Railroad proposed to construct new lines in Illinois for the diversion of general interstate and intrastate traffic. It applied beforehand to the Federal Commission which made no doubt of its jurisdiction to deal with the matter, though then merely in a state of contemplation. The litigation is set forth in People v. Illinois Central Ry., ${ }^{\mathbf{1 4}}$ wherein certain interested persons sought by suit in the state courts to enjoin the construction of the lines. Said the Supreme Court of Illinois: "The question of the jurisdiction of a state court to grant the relief . . . lies at the threshold."

It recited the provisions of the I920 Act and the holdings of Federal courts, and ordered the dismissal of the bill, saying:

“. . . the Southern Illinois and Kentucky Railroad Company will be an interstate carrier. . . . The Interstate Commerce Commission found, among other things, that

\footnotetext{
${ }^{11} 8$ F.(2d) I53 (I925); I6 F.(2d) 782 (I927).

12 The decision is criticised in note in (I925) 39 HARV. I. REv. 753.

${ }^{13} 47$ Sup. Ct. 768 (I927).

${ }^{14} 324$ IIl. 59r, r55 N. E. 84r (1927).
} 
the public convenience and necessity required the construction of the cutoff . . . [and] granted the requisite permission and authority for these purposes. The appellees, by the provisions of the Interstate Commerce Act, have the right to do these things without seeking any further authority. If, as the result of the instant suit, the construction of the cut-off should be enjoined, then a conflict of jurisdiction between the Commission and the state court would necessarily arise, for what was affirmed by one would be denied by the other. In such a situation the power to determine whether state action will obstruct interstate commerce inheres in the United States as an incident of its power to regulate such commerce."

The sense of unity may be taking the tinge of transportation unity rather than merely of railroad unity. In United States v. New York Central Railroad, ${ }^{15}$ the Supreme Court sustained over the heads of the District Court of three judges, an order of the Federal Commission linking the New York Barge Canal with the railroad by interchange of traffic. The lower court felt that the State was disqualified to apply for the order because not itself a common carrier. ${ }^{16}$ Stone, J., said:

"A state when its interests are concerned, as well as a private individual, whether carrier or not may file a complaint with the Commission. The Commission having jurisdiction over the carriers and facilities by which the transportation is carried on, the question is narrowed as to whether its jurisdiction extends to the entire current of commerce flowing through the terminal, although intrastate in part."

In another place he says:

"About seventy-five per cent. of the traffic passing over it (the canal) is interstate."

${ }^{15} 272$ U. S. 457 (1926).

${ }^{16}$ The state does not own barges or rolling stock; nor does it transport merchandise or operate the canal, the court explained. The order [13 F.(2d) 200 (I925)] directed the railroad to provide and maintain a transportation service between the state's Canal Basin and points on its own connecting lines and perform the operating service necessary . . "with its own motive power" and employees, making it thus the instrument to divert traffic from its own lines to the canal. 
In another waterway case, Chicago, Rock Island and Pacific Railroad Company v. United States, ${ }^{17}$ the railroad failed to enjoin enforcement of an order of the Interstate Commerce Commission which prescribed joint rail and water rates on cotton from Oklahoma points to New England ports. Said Mr. Justice Sutherland for the Court:

"Clearly the order in this respect can be sustained under the later and broader provisions of paragraph I3 of section 6, added to the Interstate Commerce Act by the Panama Canal Act.

"This addition to the Interstate Commerce Act materially extends the jurisdiction of the Commission in respect of land and water transportation and the carriers engaged in it, whenever property may be or is transported in interstate commerce by rail and water by a common carrier or carriers; and the obvious intention of Congress would be substantially limited in effect if the quoted provisions were held to be subject to the restriction that both rail and water must be used under a common control, etc. The phrase, 'except where one of the carriers is a water line', was introduced in an amendment made to the Interstate Commerce Act by the Transportation Act, I920, and it is not unreasonable to include within the scope of its reference, the then existing paragraph I3 of section 6. And this view is strengthened by the consideration that the Transportation Act, I920, as a part of the new policy which it introduced. in respect of the regulation of interstate transportation (Wisconsin R. R. Comm. v. C. B. \& Q. R. R. Co., 257 U. S. 563 [1922]; New England Divisions Case [supra note 2] at I89), directed the Commission to establish through routes, joint classifications, etc., both in respect of railroad and water carriers, 'whenever deemed by it to be necessary or desirable in the public interest,' etc. (4I Stat. 485.) And the same act declares it to be 'the policy of Congress to promote, encourage, and develop water transportation, service, and facilities in connection with the commerce of the United States, and to foster and preserve in full vigor both rail and water transportation.' Section 500, 4I Stat. 490 (Comp. St. \& I007 I $/ 4 \mathrm{k}$.)

"These and other provisions emphasize the intention of

${ }^{17} 274$ U. S. 29 (1927). 
Congress to broaden the control of the Interstate Commerce Commission over rail and water transportation and generally to extend the regulatory power of that body over all such transportation in the public interest. It would be quite inconsistent with that broad purpose to adopt the narrow construction of the statutory provisions under review which is advanced by the appellants."

The implications of the Wisconsin Passenger Fares case may result in the ultimate unprofitableness of the game of hideand-seek in Federal against state rates or vice versa. Variances in the rates have tempted the railroad users to secure a label best suited to their interests and have furnished suits so close on their facts that each new one is apparently worth gambling on. The present freight rates which make the game still possible raise the suggestion that as to them, too, there is a possible invitation to the action of the Commerce Commission. Certainly the intrastate freight structure may not work detriment to the general freight rate fabric, either.

The language as to the "law" governing the situation is not intricate, and has been restated recently in Baltimore and Ohio S. $W . R y . v$. Settle, ${ }^{18}$ where Settle sought the benefit of the Ohio rate from Oakley, Ohio, to Madisonville, Ohio (both freight stations within the city of Cincinnati) on shipments from outside the state which were billed in to Oakley. At Oakley, Settle received the cars and, without unloading and in a few days, reshipped them from Oakley to Madisonville where his factory was. His object was the saving to him on the interstate rate from origin to Oakley, plus the Ohio rate from Oakley to Madisonville-which items he paid-over the interstate rate throughout to Madisonville. He failed to attain it. The carrier's suit for the difference was successful. Speaking for the court, Mr. Justice Brandeis said:

"The rights of the shipper against the carrier are determined by law through the provisions of the tariff which are embodied in the applicable published rate. And whether

${ }^{28} 260$ U. S. 166 (I922). The case is noted (I923) 23 CoL. L. REv. 308; (I923) 36 HARv. L. ReV. 339; and in (I923) 7I U. OF PA. L. Rev. r32 on the shipper's intention as the determining factor. 
the interstate or the intrastate tariff is applicable depends upon the essential character of the movement. That the contract between the shipper and carrier does not necessarily determine the character was settled by a series of cases in which the subject received much consideration. ${ }^{18}$ And in Baer Brothers Mercantile Co. v. Denver and Rio Grande R. R. Co., 233 U. S. 479, 490, this Court held that a carrier cannot, by separating the rate into its component parts, charging local rates and issuing local waybills, convert an interstate shipment into intrastate transportation, and thereby deprive a shipper of the benefit of an appropriate rate for a through interstate movement.

"If the intention with which the shipment was made had been actually in issue, the fact that possession of the cars was taken by the shipper at Oakley and that they were not rebilled for several days, would have justified the jury in finding that it was originally the intention to end the movement at Oakley and that the rebilling to Madisonville was an afterthought. But the defendant Clephane admitted at the trial that it was intended from the beginning that the cars should go to Madisonville, . . . [which] was at all times the destination of the cars; Oakley was to be merely an intermediate stopping place; and the original intention persisted in was carried out. That the interstate journey might end at Oakley was never more than a possibility. Under these circumstances, the intention as it was carried out determined, as matter of law, the essential nature of the movement; and hence that the movement through to Madisonville was an interstate shipment. For neither through billing, uninterrupted movement, continuous possession by the carrier, nor unbroken bulk, is an essential of a through interstate shipment."

The Standard Oil Company has found the question worth litigating in a series of cases dealing with its methods for importing gasoline, oil, etc., into a state and feeding it into its amazingly effective apparatus of local distribution. In North Carolina it fought for the state rate for its distribution within North Carolina of oil which it brought from other states, in

${ }^{10}$ Southern Pacific Terminal Co. v. Interstate Commerce Commission, 219 U. S. 498 (IgII) Ohio Railroad Commission v. Worthington, 225 U. S. roI (IgI2) ; Texas \& New Orleans R. R. Co, v. Sabine Tram Co., 227 U. S. III (IgI3) ; Railroad Commission v. Texas \& Pacific Ry. Co., 229 U. S. 336 (Igr3). 
tankers to Wilmington, where they were discharged into immense storage tanks, whence distribution was made, partly by wagon, and partly by rail in tank cars to North Carolina points. It sought to enjoin the railroads from charging the interstate tariff on these tank cars. Standard Oil Co. of New Jersey v. Atlantic Coast Line $R y_{.},{ }^{20}$ records its victory in the District Court of North Carolina which it retained in the Circuit Court of Appeals, 4th Circuit. ${ }^{21}$ In October, I926, the Supreme Court denied a petition for a writ of certiorari. ${ }^{22}$

The District Court after reviewing the cases proceeded to a conclusion that on the facts the shipments

"reached a physical rest at Wilmington, a place of storage for distribution in a new commerce within the state . . . for the avowed and admitted purpose of ultimate reshipment by distinct and separate consignments over new carriers not to one point only and to a particular place of business of the complainant, but to many places of local distribution,"

distinguishing the Settle case. Of this the Circuit Court of Appeals which also wrote a review of the cases, said: "We concur in the conclusion reached."

The Company put the same problem before the Kentucky District Court in Standard Oil Co. of $K y$. v. Atlantic Coast Line $R$. R. $\mathrm{Co.}^{23}$ as to its distribution in Florida from its storage tanks in Port Tampa and Jacksonville. It won a complete initial success, but the Circuit Court of Appeals of the Sixth Circuit, ${ }^{24}$ undertook to differentiate the oils in a manner which apparently was not presented to the North Carolina court and the victory of the Standard was modified. The Circuit Court in this latter case asked, substantially, what oil was for general and what for special distribution and granted the intrastate rate from the pri-

${ }^{20} 6$ F.(2d) 9 II (I925). Noted "When does stoppage break the continuity of interstate shipment?" (I926) 74 U. of PA. L. REV. 390.

21 I2 F.(2d) 54 I (I926).

${ }^{22} 272$ U. S. 69I (I926).

${ }^{23}$ I3 F.(2d) 633 (1926).

2 I6 F.(2d) 44I (I926). 
mary tank, only to the former oil. As to the latter oil the court said:

"This is substantially all sold by the Company to various manufacturers-the ultimate users-upon annual contracts to supply them with stated quantities or with their needs during the period. . . . In our judgment this oil travels on a substantially continuous trip . . . to the interior points in Florida, and the Port Tampa tanks are a pond or equalizing reservoir"

as were the Stockyards, the court goes on to say, in Stafford $v$. Wallace, ${ }^{25}$ which held the cattle in them to be still in interstate traffic and subject to Federal supervision. ${ }^{26}$ It therefore applied the interstate rate to the whole transit of this oil. The court treated the oil which went through the Port Tampa tanks and was intended for the company's bulk station in the same way, saying: "It is the latter not the former which are the company's points of distribution for public use." ${ }^{27}$ Thus, only oil uncontracted for,

${ }^{23} 258$ U. S. 495 (I922).

${ }^{26}$ See Packers and Stockyards Act of I921, (1922) 22 CoL. L. Rev. 68.

${ }^{27}$ The Court at this point remarked: "We do not intend to say that these (contract and bulk station) oils may not be subject to state taxation at Port Tampa; that question is not involved."

In another aspect, since the oil was going out of Texas, rather than into the state, it was, however, directly raised in City of Galveston v. Mexican Petroleum Corp., I5 Fed. (2d) 208 (S. D. Tex. I926). Oil was brought to Galveston in tankers from Mexico and from Galveston distributed under prior contract to interstate buyers outside Galveston with a few spot sales there. The court held the oil not taxable by Galveston. "I cannot give my assent to the view of the Supreme Court of Maine in Mexican Petroleum Company v. Portland, I2I Me. 128 (1922), that the tanker is the original package in the sense of the constitutional question," said Hutcheson, D. J. See note (I927) II Minn. L. REv. 368.

In Gulf Refining Co. v. Phillips Tax Collector, II F.(2d) 967 (I926), the Circuit Court of Appeals, Fifth Circuit, held valid a tax by the Louisiana parish in which the tanks were located. It appears that to them was brought oil from Arkansas on its way to refineries in Texas. It found that the collection of the oil in Louisiana was an intentional detention for the beneficial purposes of the owner (to select the fresher oil for refining as fresh oil gives more gasoline) within Champlain Co. v. Brattleboro, 260 U. S. 366 (I922).

In Hughes Bros. Timber Co. v. Minneapolis, 272 U. S. 469 (I926), the State sued to collect taxes as of May I on certain pulp wood and was resisted on the assertion that the wood was in transit in interstate commerce. The wood was cut in various places in Minnesota, hauled to the Swamp River and piled upon its banks near the Pigeon, and at the confluence with the Pigeon delivered under a contract with a Michigan paper company from the booms there to vessels sent by the latter for transfer to its mills. The collection on the banks ended in March and the logs were started on April 29th when the ice broke and 18 days consumed in getting them to the booms. The last of them were shipped by late July. In upsetting the state court which sustained the tax, Taft, 
and oil for stations which distribute directly to the consumers secured the intrastate rates.

The narrowness of the distinctions no doubt adds zest to such litigation, for the Standard Oil Company and the railroad both secured writs of certiorari, and, in Atlantic Coast Line R. R. Co. v. Standard Oil Co., ${ }^{27 a}$ Chief Justice Taft, for the court, upset the differentiation and wholly affirmed the District Court, saying:

"It seems very clear to us on a broad view of the facts that the interstate or foreign commerce in all this oil ends upon its delivery to the plaintiff into the storage tanks or the storage tank cars at the seaboard, and that from there its distribution to storage tanks, tank cars, bulk stations and drive-in stations, or directly by tank wagons to customers, is all intrastate commerce. This distribution is the whole business of the plaintiff in Florida. There is no destination intended and arranged for with the ship carriers in Florida at any point beyond the deliveries from the vessels to the storage tanks or tank cars of the plaintiff. There is no designation of any particular oil for any particular place within Florida beyond the storage receptacles or storage tank cars into which the oil is first delivered by the ships. The title to the oil in bulk passes to the plaintiff as it is thus delivered. When the oil reaches these storage places along the Florida seaboard, it is within the control and ownership of the plaintiff for use for its particular purposes in Florida. The plaintiff is free to distribute the oil according to the demands of its business, and it arranges its storage capacity to meet the future variation in its business needs at Tampa, Port Tampa, or Jacksonville, or St. Johns River terminal.

"The important controlling fact in the present controversy, and what characterizes the nature of the commerce involved, is that the plaintiff's whole plan is to arrange deliveries of all of its oil purchases on the seaboard of Florida so that they may all be there stored for convenient distribution in the state to the I23 bulk stations and to fuel oil plants in varying quantities according to the demand of the plaintiff's

C. J., said: "The change in the method of transportation by floating to carriage on a vessel did not affect the continuity of the interstate passage, if such a passage was intended by the parties and had begun, any more than did shipment by local railroad bills of lading from a point in a state to a port of the same state, for shipment by vessel to a foreign port, prevent its being interstate or foreign commerce."

${ }^{272} 48$ Sup. Ct. I07 (I927). 
customers, and thence be distributed to subordinate centers and delivery stations, and this plan is being carried out daily. There is neither necessity nor purpose to send the oil through these seaboard storage stations to interior points by immediate continuity of transportation. The seaboard storage stations are the natural places for a change from interstate and foreign transportation to that which is intrastate, and there is nothing in the history of the whole transaction which makes them otherwise, either in intent or in fact." 28

It specifically approved the result reached by the State court in directing, in mandamus proceedings, compliance with the tariffs for the Florida hauls as prescribed by the Florida Commission: State ex rel. Burr v. A.C.L.R. Co. ${ }^{28 a}$

The Supreme Court also said: "We concur in the reasoning and conclusions of the United States circuit court of appeals for the fourth circuit, in Atlantic Coast Line R. Co. v. Standard Oil Co., I2 F. 2d 54I."

Whether interstate or state rates were to be applied was again before the District Court of North Carolina in Seaboard Air Line Ry., et al. v. Lee, et al., ${ }^{29}$ where the carrier sought to enjoin the North Carolina Corporation Commission from enforcing its order to apply intrastate rates on nitrate from Wilmington, N. C., to interior points in the state. The port to which the cargo is destined is not indicated until the vessels, which come from Chile, reach the Panama Canal and is then determined by the stocks on hand and demands at various Atlantic ports. If

${ }^{28}$ The court said: "The case is like that of General Oil Co. v. Crain, 209 U. S. 2II, in which the General Oil Company sought an injunction against the collection of a tax for the inspection of certain of its oils in Tennessee, which it had brought into Tennessee and stored in tanks, and marked in storage tanks as oil already sold in Arkansas, Louisiana and Mississippi, and which remained in Tennessee only long enough to be properly distributed according to the orders therefor, and other oil in other tanks marked to be sold in those states but for which no orders at the time of shipment from the manufacturing plants had been received. This court held that the Tennessee tax was not a burden on interstate commerce as applied to oil coming from certain states though ultimately intended for sale and distribution in states other than Tennessee; that the oil was subject to a tax while it was being stored in Tennessee for convenience of distribution and for reshipping in tank cars and barrels; that this was business done in Tennessee, where the oil was brought to rest, and was for a purpose outside its mere transportation."

${ }^{25 a}$ I09 So. 656 (I926).

${ }^{20}$ I4 F. (2d) 439 (I926). Noted in (1927) 5 N. C. L. REv. 355. 
Wilmington is designated, the bags are there landed and delivered at the dock to the importer who marks for his customers and delivers to Heide and Co., a common agent for them. About 80 per cent. is reshipped from shipside to these purchasers within the state and they pay the freight for this haul. The District Court of three judges denied an injunction.

Judge Meekins, who wrote the opinion in the Standard Oil case, $^{30}$ here answered the question "Whose intention governs?" He said:

"The essential character of the commerce is to be determined . . . by the original and persisting intention of the shipper, using that term in the sense of him for whose benefit the shipment is made, or, as it is sometimes expressed, by the intention of the shipper, which is carried out.

"It is entirely clear that, at the time a cargo of nitrate starts from Chile, the importer has no intention that its ultimate destination shall be an interior point in the state. Indeed, it is unknown at such time to which port of entry the vessel will proceed. The importer knows, of course, that . . . a cargo, or a large part thereof, consigned to Wilmington, will ultimately find its way, in segregated lots, to the manufacturers and the agriculturists located in the trade territory of that port. $\mathrm{He}$ knows further, of course, that interior movements of the products must proceed by rail from Wilmington. But this is very different from saying that he intends, at the time of consigning a cargo to Wilmington, to reship it from that point in mere continuation of the original movement from Chile.

"On the other hand, the record conclusively shows that his intention is fully carried out, and his purposes fully subserved, when the cargo is delivered to him at Wilmington. - . As aforesaid, his contracts call uniformly for delivery at Wilmington. Why, then, should he make shipment to an interior point in the state? Manifestly the sole result of so doing would be to require a reshipment to the port before delivery could be enforced.

"It is insisted, however, that the importer could as readily make contracts calling for delivery at interior points. This may or may not be true. In any event, there is no legal requirement that he do so. The record carries no sug-

${ }^{20}$ Supra note 20. 
gestion that the method of shipment and dealing described is fraudulently resorted to or otherwise adopted in order to defeat the application of the interstate tate."

The trend toward uniformity heretofore remarked on is evidenced in the Federal Supreme Court's reversal of the Arkansas Court in Missouri Pacific Ry. v. Porter. $^{31}$ The Missouri Pacific received in Arkansas cotton for which it issued an export bill of lading in two parts, of which the first part covered the Arkansas-Brunswick, Georgia, rail haul; the second the Brunswick-England ocean haul by vessels operating under the British flag. As applicable to the first part it stipulated exemption from loss by fire, which, though permissible if Federal law governed, ${ }^{32}$ was specifically invalidated by Arkansas statutes. These Arkansas statutes, however, the Arkansas court applied, on the theory that the Interstate Commerce Act did not cover the particular transit. ${ }^{33}$

In Missouri Pacific Ry. v. Porter, ${ }^{34}$ Mr. Justice Butler, for the court, decided that the Arkansas statute could not be applied. He said:

"Section 25, added by the amendment of February 28, I920, 4 I Stat. 497, § 44I (Comp. St. § 8596a), was enacted to promote the business of common carriers by water in foreign commerce whose vessels are registered under the laws of the United States; it applies to shipments from points in the United States to nonadjacent foreign countries and requires the commission to do certain things in furtherance and regulation thereof. Subdivision 4 of that

${ }^{31}$ I68 Ark. 22, 269 S. W. 47 (I925); Wolff and Co. v. Missouri, Kansas and Texas Ry., 289 S. W. 1000 (I927), is a similar case on the facts with the exception that the haul originated in Texas and the ocean port was Galveston. The Texas court gave judgment for the plaintiff.

${ }^{32}$ Cau v. Texas Pacific Ry., I94 U. S. 427 (I904).

${ }^{33}$ It read the Acts of Congress regulating bills of lading to apply only to interstate commerce, and to shipments from the United States to adjacent foreign countries. This seems proper enough, for the language of the statutes which empower the Commerce Commission to regulate bills of lading read "point in United States to an adjacent foreign territory," 38 STAT. rr97. In I920, 4I STAT. 4, extended the regulation to shipments to non-adjacent foreign territory when made in a vessel of United States registry. It is not clear that the Arkansas court ruled on this last, but the ship here was foreign.

${ }^{4} 273$ U. S. 34 I (I927). 
section requires a railroad carrier receiving a shipment to be delivered to such a vessel for further transportation to issue a through bill of lading which shall state separately the amount to be paid for railroad transportation, for water transportation and in addition, if any, for port charges. It requires the railroad as a part of its undertaking to deliver the shipment to the vessel and provides that it will not be responsible after such delivery. The commission is expressly empowered, in such manner as will preserve for the carrier by water the protection of limited liability provided by law, to prescribe the form of such bills of lading. The section does not apply to shipments in such commerce where the ocean carriage is by a foreign vessel. The record does not disclose whether the vessel on which the cotton was to have been carried was registered under the laws of the United States; and, in favor of the shippers, we assume it was a foreign vessel.

"The question is whether Congress has entered upon the regulation of provisions in bills of lading affecting liability of railroads for loss of property received by them for transportation over an interstate inland route to a seaport for delivery to a foreign vessel for ocean carriage to a nonadjacent foreign country. . . . No act of Congress or order of the commission prescribed a form of bill of lading for this shipment. . . . The defendants-in-error rightly say that the Carmack Amendment, the Cummins Amendment, or section 25 does not apply to such a shipment. But that does not sustain their contention that Congress has not evinced an intention to regulate bills of lading for transportation such as is here involved. Section I (6) extends to all carriers and to all transportation subject to the act; it prescribes a general rule applicable to all regulations and practices affecting the form or substance of bills of lading in order that they may be just and reasonable. And the Commission is empowered and directed to enforce the rule.

"The general regulation of the "issuance, form, and substance' of bills of lading is broad enough to cover contractual provisions, like the one involved in this case, exempting railroads from liability for loss of shippers' property by fire. Congress must be deemed to have determined that the rule laid down and the means provided to enforce it are sufficient and that no other regulation is necessary. Its power to regulate such commerce and all its instrumentalities is supreme; and, as that power has been exerted, 
state laws have no application. They cannot be applied in coincidence with, as complementary to or as in opposition to, federal enactments which disclose the intention of Congress to enter a field of regulation that is within its jurisdiction." ${ }^{35}$

The result achieved by this exhibition of main strength in filling statutory gaps is no doubt a desirable addition to the uniformity of the law applicable to carriage which extends outside any particular state. Presumably the decision of the Texas court in Wolff and Co. v. Missouri, Kansas and Texas Ry., ${ }^{36}$ is affected by it though the difference in the haul is a possible basis for distinction.

On the more direct phases of control in the interacting areas of state and federal authority there have been lately a number of decisions which illustrate that tightening of the web of Federal regulation, which the logic of the new view of the railroads imposes, and which the situation, in itself, requires. The formula which dominates the field is well known. It was restated in $D i$ Santo v. Commission of Pennsylvania, ${ }^{37}$ which reversed a conviction, in the Pennsylvania courts, for violating a state law requiring the sellers of steamship tickets or orders for transportation to or from foreign countries to be licensed. Mr. Justice Butler, for the court, disposed of the case in a paragraph, saying:

"The soliciting of passengers and the sale of steamship tickets and orders for passage between the United

${ }^{85}$ The case is noted (I927) 25 MICH. L. REv. 902, and characterized as judicial legislation. It is also noted in (I927) 40 HARV. L. REV. II30-5, "Foreign Commerce and the Interstate Commerce Act." So far as judicial legislation goes the court had already in Galveston, etc., Ry. v. Woodbury, 257 U. S. 357 (I920) applied the "from United States to an adjacent country" provision of the act to a haul from the adjacent country to the United States, in sustaining a limitation of baggage liability.

${ }^{36}$ Supra note 3I.

${ }^{37} 273$ U. S. 34 (I927). The case is noted (I927) 27 CoL. L. REv. 573, The "Direct Burden" Test of the Constitutionality of State Statutes Affecting Interstate Commerce; (1927) 22 ILI. L. REv. I97; (I927) 5 N. C. L. REv. 318; (I927) 5 TEx. L. REv. 3 I8. In The Silence of Congress, (I928) $4 \mathrm{I}$ HARv. L. Rev. 200, Mr. Henry Wolf Bikle discusses some of the inconsistencies which appear in the principles as announced by the court.

In a note on the jurisdiction of the Federal Trade Commission E. F. Albertsworth deals with the question "What is interstate commerce?" generally, in (1927) 22 ILL. L. REv. 304. He says delimitation is not possible. 
States and Europe constitute a well-recognized part of foreign commerce. . . . A state statute which by its necessary operation directly interferes with or burdens foreign commerce is a prohibited regulation and invalid regardless of the purpose with which it was passed. . . . Such legislation cannot be sustained as an exertion of the police power of the state to prevent possible fraud. . . . The Congress has complete and paramount authority to regulate foreign commerce and, by appropriate measures, to protect the public against frauds of those who sell these tickets and orders. The sales here in question are related to foreign commerce as directly as are sales made in ticket offices maintained by the carriers and operated by their servants and employees. The license fee and other things imposed by the act on plaintiff-in-error, who initiates for his principals a transaction in foreign commerce, constitute a direct burden on that commerce."

Justices Brandeis and Holmes dissented, the former saying:

"The fact that the sale of the ticket is made as a part of a transaction in foreign or interstate commerce does not preclude application of state inspection laws, where, as here, Congress has not entered the field, and the state regulation neither obstructs, discriminates against, nor directly burdens the commerce."

And he recites in brief the facts and holdings of twentyfive to thirty cases on the topic, concluding:

"In the search for truth through the slow process of inclusion and exclusion, involving trial and error, it behooves us to reject, as guides, the decisions upon such questions which prove to have been mistaken. This course seems to me imperative when, as here, the decision to be made involves the delicate adjustment of conflicting claims of the federal government and the states to regulate commerce. The many cases on the commerce clause in which this court has overruled or explained away its earlier decisions show that the wisdom of this course has been heretofore recognized. In the case at bar, also, the logic of words should yield to the logic of realities." 
Mr. Justice Stone who also dissented said:

"In this case the traditional test of the limit of state action by inquiring whether the interference with commerce is direct or indirect seems to me too mechanical, too uncertain in its application, and too remote from actualities, to be of value. In thus making use of the expressions 'direct' and 'indirect interference' with commerce, we are doing little more than using labels to describe a result rather than any trustworthy formula by which it is.reached.

"It is difficult to say that such permitted interferences as those enumerated in Mr. Justice Brandeis' opinion are less direct than the interference prohibited here. But it seems clear that those interferences not deemed forbidden are to be sustained; not because the effect on commerce is nominally indirect, but because a consideration of all the facts and circumstances, such as the nature of the regulation, its function, the character of the business involved and the actual effect on the flow of commerce, lead to the conclusion that the regulation concerns interests peculiarly local and does not infringe the national interest in maintaining the freedom of commerce across state lines.

"I am not persuaded that the regulation here is more than local in character. Until Congress undertakes the protection of local communities from the dishonesty of the sellers of steamship tickets, it would seem that there is no adequate ground for holding that the regulation here involved is a prohibited interference with commerce."

After such judicial remarks as these the commentator recalls the reply of Dr. Johnson to Boswell's question about supporting a bad case. "Sir, you do not know it to be good or bad till the Judge determine it." Predictability and client advising become impossible. Yet the blessing of the open concept may outweigh these detriments and leave criticism to deal with results merely.

The last sentences quoted from the two dissenting opinions serve to point out the unfortunate character of the decision under the present circumstances. The needs, which the justices from the great seaboard sensed, plus the fact that Congress was not in the field and could by entering it oust any state which already had entered it, make the case apparently an example of a merely 
blind urge toward Federal control rather than a factually justifiable thing, since chinking a gap with Federal authority in the abstract, when actual exercise of Federal authority was lacking, operated to leave an open gap uncovered by any authority at all. Accepting the hypothesis of a need, the decision holds a direct invitation to Congress to "do something." But if the case had gone the way of the dissenters, the state authority could no doubt have handled the situation effectively if temporarily.

The case of the Priblic Utilities Commission of Rhode Island v. Attleboro Steam and Electric Co., ${ }^{38}$ is another direct invitation to Congress to do something in an instance where, however, the effectiveness of state action is more than doubtful. Briefly, the facts are that the Narragansett Electric Light Co., a Rhode Island corporation, generated, in Rhode Island, current which it sold in part ${ }^{39}$ to the Attleboro Company which retailed it in its Massachusetts city to its local consumers. The arrangement dated from I9I7 and was expressed in figures, appropriate to its date, but rendered highly unpalateable to the Narragansett Company by post-war conditions. The latter therefore made application for an increase of rates. A commission is not barred from increasing them, ${ }^{40}$ but the problem of the Narragansett Co. was "Which commission?" The point of the case is whether its guess of the Rhode Island Commission was a good one. The commission itself took jurisdiction but the Rhode Island Supreme Court held that its order granting the increase imposed a direct burden on interstate commerce ${ }^{41}$ and directed that the proceedings be dismissed. This the Federal Supreme Court

${ }^{38} 273$ U. S. 83 (I927).

20 The part was only I/35th of the total. As bearing on the question whether the matter was "local" within the jargon of the subject, more attention might have been given to the smallness of the part.

${ }^{10}$ The contract is no bar to an increase of rates. "The power of the state to regulate the selling price is not affected by the fact that the supply is furnished under a long term contract. Union Dry Goods Co. v. Georgia Public Service Corporation, 248 U. S. 372 (I919," remarked the court.

"It acted on the authority of Missouri v. Kansas Gas Co., 265 U. S. 298 (1924), which is stated in the abstract of the opinion of Mr. Justice Sanford. See Dwight Williams, The Power of the State to Control the Use of Natural Resources, (1927) II MINN. L. REV. 129, 233, 243. If a state wishes to build up industry within its borders by limiting its power exports as the local commission may decide, does the Attleboro case bar its indulgence in the policy? 
agreed with, Mr. Justice Sanford writing for the Court and Mr. Justice Brandeis dissenting.

Said Sanford, J:

"It is conceded rightly, that the sale of electric current by the Narragansett Company to the Attleboro Company is a transaction in interstate commerce, notwithstanding the fact that the current is delivered at the state line. The transmission of electric current from one state to another, like that of gas, is interstate commerce. Coal \& Coke Co. v. $P u b$. Serv. Comm., 84 W. Va. 662, 669, and its essential character is not affected by a passing of custody and title at the state boundary not arresting the continuous transmission to the intended destination. People's Gas Co. v. Pub. Serv. Comm., 270 U. S. 550 (I926).

"The petitioners contend, however, that the Rhode Island Commission cannot effectively exercise its power to regulate the rates for electricity furnished by the Narragansett Company to local [Rhode Island] consumers, without also regulating the rates for the other service which it furnishes; that if the Narragansett Company continues to furnish electricity to the Attleboro Company at a loss, this will tend to increase the burden on the local consumers and impair the ability of the Narragansett Company to give them good service at reasonable prices; and that, therefore, the order of the Commission prescribing a reasonable rate for the interstate service to the Attleboro Company should be sustained as being essentially a local regulation, necessary to the protection of matters of local interest, and affecting interstate commerce only indirectly and incidentally. In support of this contention they rely chiefly upon Pennsylvania Gas Co. v. Pub. Serv. Com., 252 U. S. 23 (I920); and the controlling question presented is whether the present case comes within the rule of the Pennsylvania Gas Co. case or that of the Kansas Gas Co. case upon which the Attleboro Company relies.

"In the Pennsylvania Gas Co. case, the company transmitted natural gas by a main pipe line from the source of supply in Pennsylvania to a point of distribution in a city in New York, which it there subdivided and sold at retail to local consumers supplied from the main by pipes laid through the streets of the city. In holding that the New York Public Service Commission might regulate the rate charged to these consumers, the court said that while a state 
may not 'directly' regulate or burden interstate commerce, it may in some instances, until the subject-matter is regulated by Congress, pass laws, 'indirectly' affecting such commerce, when needed to protect or regulate matters of local interest; that the thing which the New York Commission had undertaken to regulate, while part of an interstate transmission, was 'local in its nature,' pertaining to the furnishing of gas to local consumers, and the service rendered to them was 'essentially local' being similar to that of a local plant furnishing gas to consumers in a city; and that such 'local service' was not of the character which required general and uniform regulation of rates by congressional action, even if the local rates might 'affect' the interstate business of the company.

"In the Kansas Gas Co. case the company, whose business was principally interstate, transported natural gas by continuous pipe lines from wells in Oklahoma and Kansas into Missouri, and there sold and delivered it to distributing companies, which then sold and delivered it to local consumers. In holding that the rate which the company charged for the gas sold to the distributing companiesthose at which these companies sold to the local consumers not being involved-was not subject to regulation by the Public Utilities Commission of Missouri, the court said that, while in the absence of congressional action a state may generally enact laws of internal police, although they have an indirect effect upon interstate commerce, 'the commerce clause of the Constitution, of its own force, restrains the states from imposing direct burdens upon interstate commerce,' and a state enactment imposing such a 'direct burden' must fall, being a direct restraint of that which in the absence of federal regulation should be free, Minnesota Rate Cases, 230 U. S. 352 (I9I3); that the sale and delivery to the distributing companies was 'an inseparable part of a transaction in interstate commerce-not local but essentially national in character-and enforcement of a selling price in such a transaction places a direct burden upon such commerce inconsistent with that freedom of interstate trade which it was the purpose of the commerce clause to secure and preserve'; that in the Pennsylvania Gas Co. case the decision rested on the ground that the service to the consumers for which the regulated charge was made, was 'essentially local' and the things done were after the business in its essentially national aspect had come to an end-that 
supplying of local consumers being 'a local business,' even though the gas be brought from another state, in which the local interest is paramount and the interference with interstate commerce, if any, indirect and of minor importance; but that in the sale of gas in wholesale quantities not to consumers, but to distributing companies for resale to consumers, where the transportation, sale and delivery constitutes an unbroken chain, fundamentally interstate from beginning to end, 'the paramount interest is not local but national, admitting of and requiring uniformity of regulation,' which, 'even though it be the uniformity of governmental nonaction, may be highly necessary to preserve equality of opportunity and treatment among the various communities and states concerned.'

"It is clear that the present case is controlled by the Kansas Gas Co. case. . . . It is immaterial that the Narragansett Company is a Rhode Island corporation subject to regulation by the Commission in its local business, or that Rhode Island is the state from which the electric current is transmitted in interstate commerce, and not that in which it is received, as in the Kansas Gas Co. case. The forwarding state obviously has no more authority than the receiving state to place a direct burden upon interstate commerce. Pennsylvania v. West Virginia, 262 U. S. 553 (1923). Nor is it material that the general business of the Narragansett Company appears to be chiefly local, while in the Kansas Gas Co. case the company was principally engaged in interstate business. The test of the validity of a state regulation is not the character of the general business of the company, but whether the particular business which is regulated is essentially local or national in character; and if the regulation places a direct burden upon its interstate business it is none the less beyond the power of the state because this may be the smaller part of its general business. Furthermore, if Rhode Island could place a direct burden upon the interstate business of the Narragansett Company because this would result in indirect benefit to the customers of the Narragansett Company in Rhode Island, Massachusetts could, by parity of reasoning, reduce the rates on such interstate business in order to benefit the customers of the Attleboro Company in that state, who would have, in the aggregate, an interest in the interstate rate co-relative to that of the customers of the Narragansett Company in Rhode Island. Plainly, however, the paramount interest in 
the interstate business carried on between the two companies is not local to either state, but is essentially national in character. The rate is therefore not subject to regulation by either of the two states in the guise of protection to the respective local interests but, if such regulation is required it can only be attained by the exercise of the power vested in Congress. See Covington Bridge Co. v. Kentucky, I 54 U. S. 204 (I894); Hanley v. Kansas City S. Ry. Co., I87 U. S. 6I7 (I903)."42

If the Attleboro users of the electricity retailed to them by the Attleboro Company felt that their rates were too high, they would, naturally, apply to the Massachusetts Commission for relief; and under the Pennsylvania Gas case doctrine the Massachusetts Commission has jurisdiction to give it. If, however, the major item in the Attleboro Company's cost is-as it probably is-the price of the imported current, and that price under the contract is-as it may become if price levels drop-too high; what practical handling of the situation can the Massachusetts Commission make?

The moral, for the present, seems to be for the consumer to contract with an out of the state utility if he can. In another aspect the decision frowns upon a policy on the part of a powerproducing state, to build up industry within its borders by having its commission allot and limit the amount of current export allowed, a matter much agitated in Maine. ${ }^{43}$ As a phase of the trend toward unity, it seems a desirable propulsion of Federal

2The case was variously noted in the current law reviews: (I927) 27 CoL. L. Rev. 6I5; (I927) I5 GEORgetown L. Rev. 346; (I927) 40 HARV. L. REV. 906; (I927) 22 ILL. L. REv. I97; (I927) 26 Mich. L. Rev. I06; (I927) 36 YALE L. J. $88 \mathrm{r}$.

${ }^{4}$ Brandeis, J. (dissenting) : "If the (Rhode Island) Commission lacks the power exercised it is solely because the electricity is delivered for use in another state. That fact makes the transaction interstate commerce, and Congress has power to legislate on the subject. It has not done so, nor has it legislated on any allied subject, so there can be no contention that it has occupied the field. Nor is this a case in which it can be said that the silence of Congress is a command that the Rhode Island utility shall remain free to discriminate against the citizens of the state by which it was incorporated and in which it does business. That state may not, of course, obstruct or directly burden interstate commerce. But to prevent discrimination in the price of electricity wherever used does not obstruct or place a direct burden upon interstate commerce." Governor Brewster of Maine in various recent speeches has dealt with the export or non-export by his state of hydroelectric power: See editorial, "Maine's Water Power," Boston Herald, Sept. I9, I927. 
regulation into a field in which its unified control is demanded by the facts. The plans for superpower systems of vast scope and area, co-ordinating the use of current from water power and from coal burned at the mine, can presumably flower best under single supervision and function better under single regulationassuming regulation inevitable. The hitches in the realization of the Colorado River Water Compact leave the writer voting for a unity under Federal control. If the Secretary of Agriculture can function as a commission in Stockyard regulation ${ }^{44}$ no doubt some agency, perhaps the Federal Power Commission, can be revamped to function similarly here, but if the electrification of the railroads should follow upon the realization of the superpower scheme it might prove as undesirable that the Commerce Commission did not control the railroad power factor, as it is that the railroad wage factor is now in other hands.

"1 Packers' Act, r92I, supra note 27.

(To be concluded) 